\title{
Detection of human papillomavirus DNA sequences by in situ DNA-DNA hybridisation in cervical intraepithelial neoplasia and invasive carcinoma: a retrospective study
}

\author{
J E COLLINS, * D JENKINS, $\dagger$ D J McCANCE*
}

From the *Department of Microbiology, United Medical and Dental Schools of Guy's and St Thomas's Hospitals, and the $\dagger$ Department of Histopathology, Whittington Hospital, London

SUMMARY Human papillomavirus (HPV) infection of cervical intraepithelial neoplasia (CIN) and invasive cervical carcinoma was investigated using in situ DNA-DNA hybridisation on histological sections of formalin fixed, paraffin embedded tissue to assess the technique's sensitivity and to assess retrospectively the association between HPV16 and invasive cervical carcinoma. HPV DNA was detected in 16 of 33 biopsy specimens of CIN. Cells containing viral DNA were more numerous than those positive for viral structural proteins. HPV DNA was also present in less differentiated cells deeper in the epithelium. The detection rate in CIN was lower than that reported for other hybridisation techniques such as Southern blotting. In a retrospective study of biopsy specimens of invasive squamous carcinoma of the cervix HPV16 DNA, the virus most commonly associated with cervical malignant disease, was found in 20 of 25 cases, including those dating from as far back as 1932. The level of sensitivity was similar to that reported for other hybridisation techniques. DNA positive cells were focally distributed in the invasive tumours, and most tumour cells were negative for viral DNA, a result consistent with the low copy number found in malignant cells.

It is concluded that HPV16 is not a new virus but that its prevalence is a result of changes in sexual behaviour and that in situ hybridisation is useful in the localisation of HPV DNA replication in CIN and invasive carcinoma.

Genital human papillomaviruses (HPV) have been implicated as aetiological agents of cervical cancer. ${ }^{1-3}$ HPV types 6 and 11 are associated with condylomata acuminata $^{45}$ and low grade cervical intraepithelial neoplasia (CIN). ${ }^{3} \mathrm{HPV}$ types 16 and 18 are found in CIN of all grades and in invasive carcinoma of the cervix. ${ }^{1-3}$ HPV16 is the commonest virus found in cases of CIN worldwide ${ }^{6}$ and has been shown to be associated with an increased risk of progression from low grade to high grade CIN. ${ }^{7}$ HPV type 31 is found in about $20 \%$ of cases of CIN in the United States ${ }^{8}$ but in only $2 \%$ of a London population (McCance DJ, unpublished data).

There has been an increase in cases of CIN and invasive cervical carcinoma in women under 35 years old over the past 10 years. ${ }^{9}$ Recent studies show that

Accepted for publication 29 September 1987 most cases are associated with HPV infection. ${ }^{1-s}$ As HPV6 and HPV16 seem to be associated with lesions of different severity it may become important to have a means of distinguishing between these viruses. HPV type cannot be identified by cytological or histological criteria alone. ${ }^{10}$ At present, the identification of the type of HPV requires either DNA-DNA hybridisation after Southern blotting or in situ (dot blot) hybridisation of cervical smears. ${ }^{311} 12$ Both techniques detect HPV infection in $60-75 \%$ of cases of CIN, but are not widely available in routine pathology laboratories. Detection of viral structural antigens in histological sections of cervical biopsy specimens using commercially prepared antiserum does not differentiate between HPV types and is not as sensitive as DNA-DNA hybridisation. Only about $30-35 \%$ of cases of CIN are positive for HPV by this method, and it has been shown to be of only limited value in routine practice. ${ }^{13}$ In situ DNA-DNA hybridisation is quicker and 
technically easier than the Southern blot technique and can be performed on sections of formalin fixed, paraffin embedded cervical biopsy specimens used for routine histological diagnosis. To assess the sensitivity of this test and study retrospectively the association of HPV16 with invasive cervical cancer in archived biopsy specimens taken between 1932 and 1986, we developed an in situ hybridisation technique using ${ }^{35}$ S-labelled DNA based on previously reported methods. ${ }^{14} 15$

\section{Material and methods}

Tissue fixed in formol-mercury and embedded in paraffin from 33 routine cervical colposcopic biopsy specimens of CIN of all grades, obtained during 1985 and 1986 was examined, together with 30 formalin fixed biopsy specimens of invasive cervical cancer from each decade between 1932 and 1986 and archived at the Whittington Hospital. Sections were cut at $4 \mu \mathrm{m}$ and mounted on slides cleaned with acid and coated with poly-L-lysine. These were then air dried and baked at $60^{\circ} \mathrm{C}$ overnight. 3-amino-propylethoxysilane (APES) was used to improve adhesion of tissue sections. ${ }^{1617}$

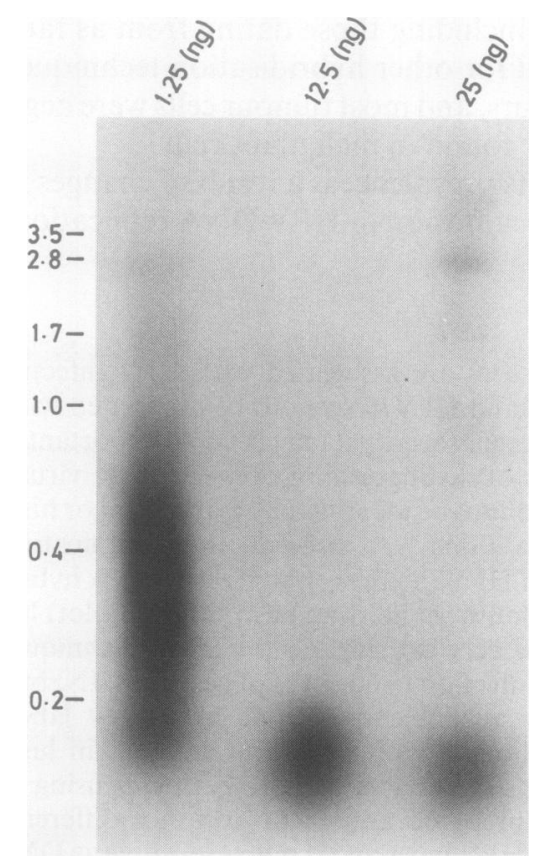

Fig 1 Autoradiograph of ${ }^{35} S$-labelled DNA probes indicating size of fragments obtained using different concentrations of DNAse in a nick translation reaction. Size markers in kilobases are indicated on left of figure and concentrations of DNAse ( $\mathrm{ng} / \mathrm{ml}$ ) along the top.
PREPARATION OF DNA PROBES

Linear HPV16 DNA was digested with the restriction endonuclease Pst 1 and radiolabelled in vitro by nick translation using ${ }^{35} \mathrm{~S}$ dCTP. ${ }^{18}$ Digestion of HPV16 DNA with Pst 1 gives band sizes ranging from 2.8 kilobases $(\mathrm{kb})$ to $0 \cdot 2 \mathrm{~kb}$. Smaller sized bands were then produced by using different concentrations of deoxyribonuclease (DNAse) during nick translation (fig 1). HPV6 DNA was treated similarly. For formalin fixed sections, a DNAse concentration of $1.25 \mathrm{ng} / \mathrm{ml}$ was used, producing DNA of $200-400$ base pairs.

To separate unincorporated triphosphates from the labelled probe the DNA was precipitated with $100 \mu \mathrm{g}$ of tRNA in 0.1 volume of sodium acetate and two volumes of ethanol, washed in $70 \%$ ethanol, resuspended, and precipitated again. The dried pellet was resuspended in the hybridisation mix of $40 \%$ deionised formamide, $2 \times \mathrm{SSC}(1 \times \mathrm{SSC}=0.15 \mathrm{M}$ sodium chloride and $0.015 \mathrm{M}$ sodium citrate), $10 \times$ Denhardt's solution (Denhardt $\times 1=0.02 \%$ bovine serum albumin, $0.02 \%$ polyvinyl-pyrrolidone, and $0.02 \%$ Ficoll), $500 \mu \mathrm{g} / \mathrm{ml}$ sheared salmon sperm DNA, $10 \%$ dextran sulphate, and $2 \mu \mathrm{g} / \mathrm{ml}$ of labelled probe.

PREPARATION OF SECTIONS FOR HYBRIDISATION Sections were dewaxed in xylene for 10 minutes, washed twice in alcohol, and hydrated in water. Tissue fixed in formol-mercury was incubated in $0.5 \%$ iodine in $70 \%$ ethanol for five minutes and then bleached in $5 \%$ sodium thiosulphate to remove the mercury. The sections were treated with $0 \cdot 2 \mathrm{~N}$ hydrochloric acid for 20 minutes at room temperature, washed, and incubated with proteinase $\mathrm{K}(2 \mathrm{mg} / \mathrm{ml}$, Boehringer, Mannheim), dissolved in $50 \mathrm{mM}$ Tris (pH 7.5), and $5 \mathrm{mM}$ edetic acid for five minutes at room temperature. Digestion was stopped by washing in $100 \mathrm{mM}$ Tris (pH 7.5), $100 \mathrm{mM}$ sodium chloride, and $2 \mathrm{mg} / \mathrm{ml}$ glycine solution. Finally, the sections were dehydrated through graded alcohols and air dried.

\section{DNA-DNA HYBRIDISATION}

A minimum of three sections from each biopsy specimen was investigated for the presence of HPV DNA. At least $25 \mu \mathrm{l}$ of hybridisation mix $(2 \mu \mathrm{g} / \mathrm{ml}$ of probe) was pipetted on to the prepared slides and a siliconised coverslip placed over the section. Denaturation followed in a moist chamber using a hot air oven maintained at $95^{\circ} \mathrm{C}$ for 10 minutes. Hybridisation continued in the moist chamber for 16 hours at $37^{\circ} \mathrm{C}$, at $25^{\circ} \mathrm{C}$ below melting temperature (Tm). After hybridisation the sections were washed at $37^{\circ} \mathrm{C}$ in $50 \%$ deionised formamide and $2 \times$ SSC for two periods of 15 minutes $\left(17^{\circ} \mathrm{C}\right.$ below Tm), followed by $2 \times \mathrm{SSC}$ for a further two periods of 15 minutes.

Autoradiography was performed using emulsion $\mathrm{K} 2$ (Ilford) melted at $42^{\circ} \mathrm{C}$ and diluted $1 / 1$ with $10 \%$ 
glycerol. After a five day exposure slides were developed for four minutes in D-19 developer (Kodak), rinsed, and fixed for four minutes in Hypan fixative (Ilford). Sections were then counterstained with haematoxylin, dehydrated, and mounted.

\section{IMMUNOCYTOCHEMICAL STAINING}

Sections were stained with a genus specific bovine papillomavirus antibody (Dako B580) at $1 / 300$ as previously described.$^{13}$ Some sections which had been stained for viral antigens were then processed for DNA-DNA hybridisation. Triton $X(0.1 \%)$ was added to the hybridisation mix to prevent non-specific binding of the probe to positively stained cells. ${ }^{19}$

\section{Results}

\section{PENETRATION OF DNA PROBES}

To facilitate penetration of the probe into cells in tissues fixed by formalin, proteinase digestion and the use of fragmented DNA were found to be necessary. Proteinase digestion was critical and $2 \mathrm{mg} / \mathrm{ml}$ of proteinase $\mathrm{K}$ for five minutes at room temperature was found to be optimal.
Digestion of the DNA probe with the restriction endonuclease $P$ st 1 and nick translation with a DNAse concentration of $1.25 \mathrm{ng} / \mathrm{ml}$ produced a probe mostly of $200-400$ base pairs in length (fig 1 ).

SPECIFICITY AND SENSITIVITY OF DNA PROBES The specificities of the probes were tested in three ways. In one test a condylomata containing HPV6 DNA (fig 2a) was hybridised with HPV type 16 DNA and no signals were observed (fig $2 b$ ). Secondly, a 1000 -fold excess of unlabelled HPV6 DNA was hybridised along with the ${ }^{35} \mathrm{~S}$-labelled HPV probe and no signal was detected by autoradiography. Thirdly, a biopsy section of the same HPV6 containing lesion was hybridised with ${ }^{35}$ S-labelled HPV type 1 DNA. This virus causes verruca plantaris and has never been detected in genital lesions. No signals were observed by autoradiography.

The method used detected HPV in Caski cells at a level of 600 copies/cell, ${ }^{20}$ HT-156.35 cells at $50-100$ copies/cell (a gift of Dr L Kelland, Royal Marsden Hospital, Sutton, England), but not in Siha cells at 110 copies/cell. ${ }^{18}$ This suggests that the method can detect at least as few as $\mathbf{5 0}$ copies per cell.

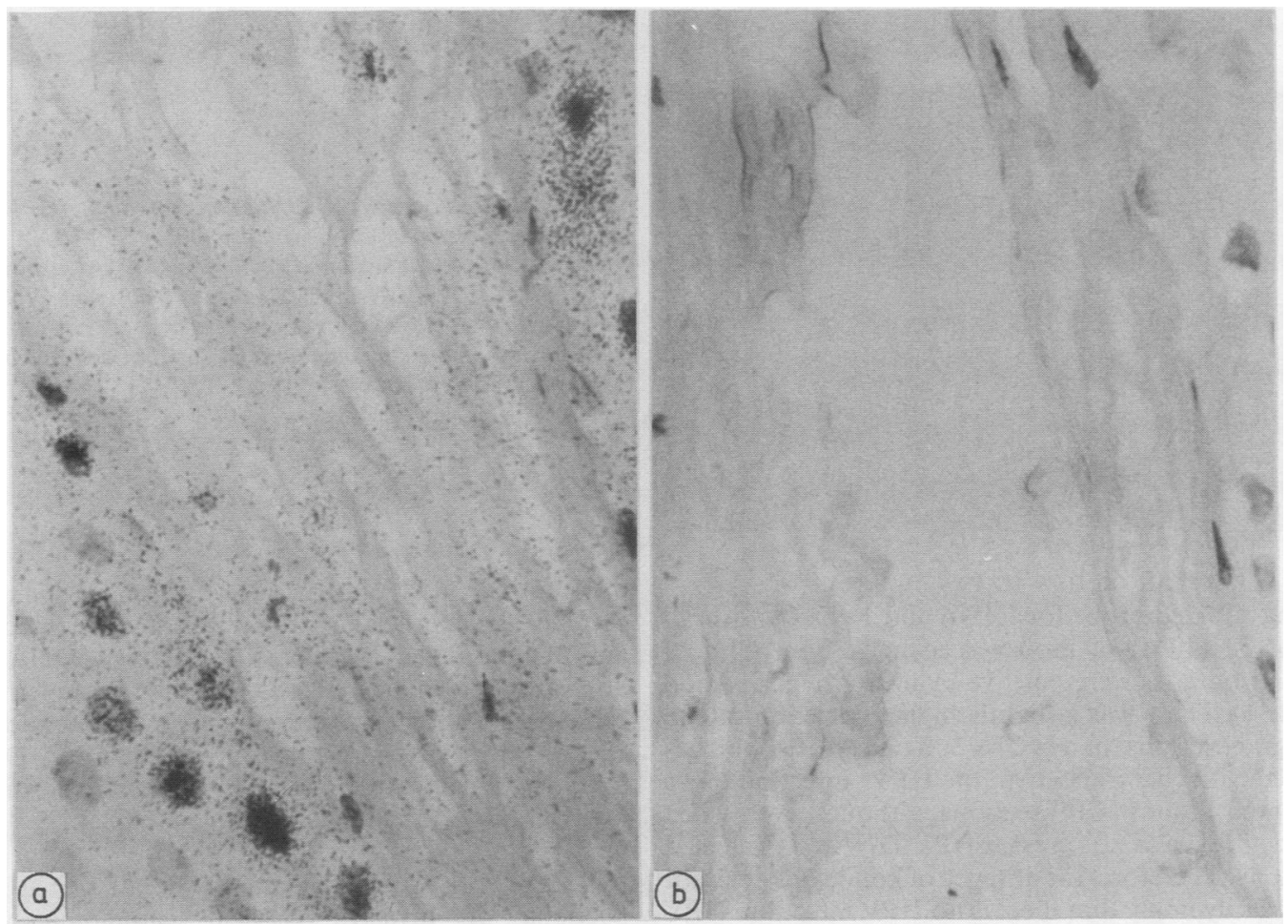

Fig 2 Autoradiographs of condyloma containing HPV6 DNA (a) ${ }^{35} S$-labelled linear HPV6 DNA; (b) ${ }^{35} S$ labelled linear HPV16 DNA. 

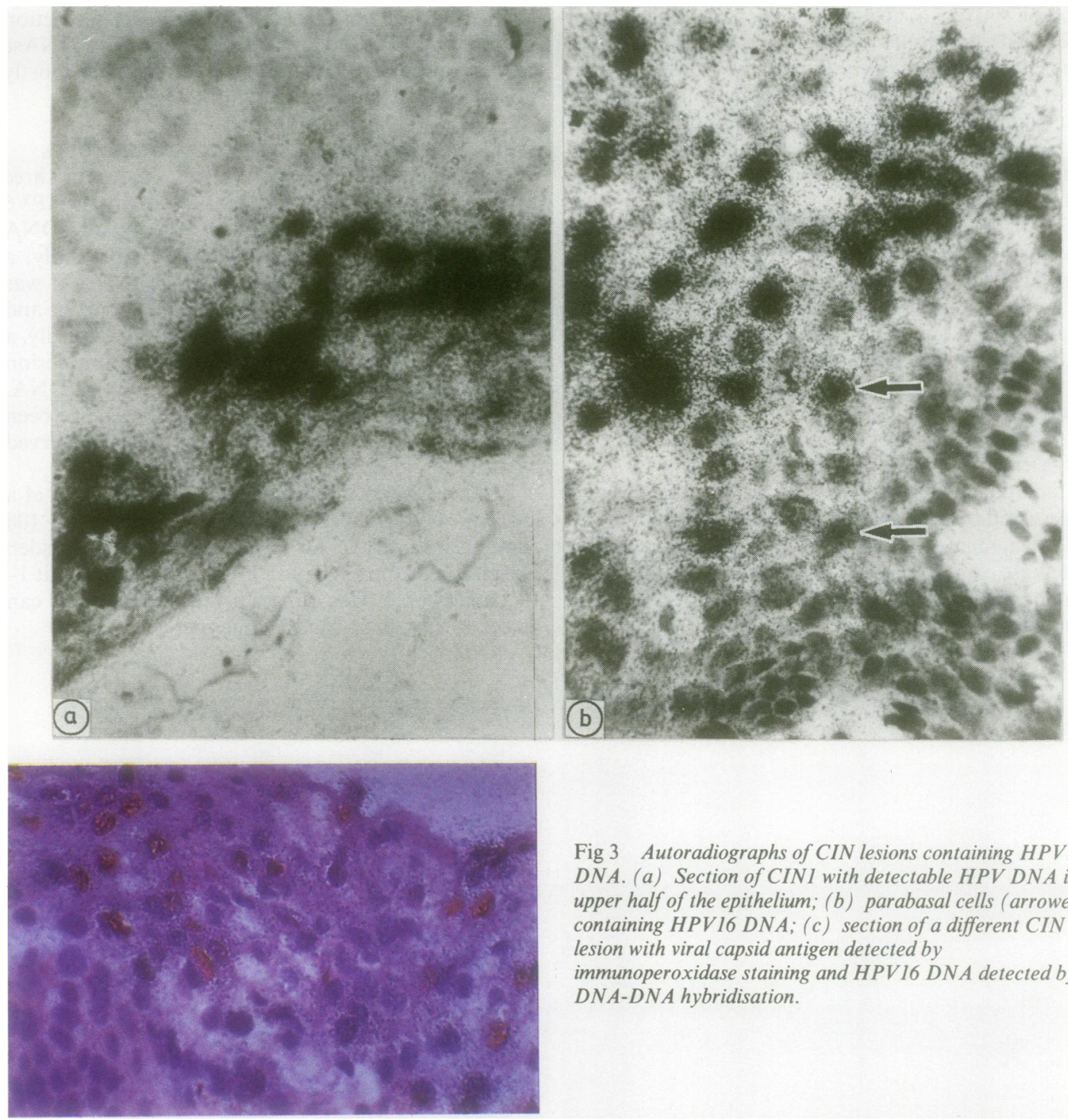

Fig 3 Autoradiographs of CIN lesions containing HPV16 DNA. (a) Section of CINI with detectable HPV DNA in upper half of the epithelium; (b) parabasal cells (arrowed) containing HPVI6 DNA; (c) section of a different CIN lesion with viral capsid antigen detected by immunoperoxidase staining and HPVI6 DNA detected by DNA-DNA hybridisation.

LOCALISATION OF HPV IN CIN

Using a mixed probe for HPV6 and 16 DNA, overall 16 of $33(49 \%)$ of biopsy specimens from CIN of different grades were positive by in situ hybridisation (table 1). There was a slightly higher detection rate in low grade lesions than in CIN 3. Koilocytosis, which is thought to be indicative of HPV infection, was observed in most CIN sections, although even when koilocytosis was not present HPV DNA was detected (table 1). Therefore, the absence of koilocytes does not necessarily imply that there is no HPV infection. HPV DNA was shown mostly in differentiated cells in the upper half of the epithelium (fig 3a). Unlike the distribution of HPV structural antigens, which are confined to superficial mature cells, some intermediate and parabasal cells were positive for HPV DNA (fig $3 b$ ), although the signal was less than in superficial cells. Sections which were stained by immunocytochemistry for viral antigens followed by DNA-DNA hybridisation always showed more extensive positivity for viral DNA than for viral antigen (fig 3c).

\section{INVASIVE CER VICAL CARCINOMA}

Sections of invasive cervical carcinoma were hybridised with HPV16 DNA. In previous studies on fresh tissue using the Southern blotting technique we 
Table 1 Detection of HPV DNA sequences in sections from CIN biopsy specimens

\begin{tabular}{llll}
\hline & $\begin{array}{l}\text { No positive for HPV6 } \\
\text { and l6 in presence or } \\
\text { absence of koilocytes }\end{array}$ & $\begin{array}{l}\text { Total No } \\
\text { positive for } \\
\text { Grade of }\end{array}$ & APV DNA \\
\cline { 2 - 2 }$(n=)$ & Presence & Absence & \\
\hline CIN1 (10) & $4 / 8$ & $2 / 2$ & 6 \\
CIN2 (6) & $3 / 5$ & $0 / 1$ & 3 \\
CIN3 (17) & $5 / 14$ & $2 / 3$ & 7 \\
Total (33) & $12 / 27$ & $4 / 6$ & $16 / 33$ \\
\hline
\end{tabular}

Table 2 Detection of HPV type 16 DNA in invasive cervical carcinoma specimens

\begin{tabular}{ll}
\hline Decade $(n=)$ & HPVI6 DNA positive \\
\hline $1980(6)$ & 6 \\
$1970(8)$ & 6 \\
$1960(5)$ & 4 \\
$1950(5)$ & $0^{*}$ \\
$1940(2)$ & $3^{+}$ \\
$1930(4)$ &
\end{tabular}

*Only one section from one biopsy specimen remained on the slides after processing; ${ }^{+}$the year of the earliest biopsy was 1932.

detected only HPV16 in malignant disease in our clinic population. $^{3}$ Sections from carcinomas were hybridised with HPV6 DNA as a control for specificity.

Although 30 specimens of invasive carcinomas taken between 1932 and 1986 were investigated, results were available from only 25 because of detachment of sections from slides during the processing of tissue from the $1950 \mathrm{~s}$. Twenty of the $25(80 \%)$ were positive for HPV16 DNA (table 2). The earliest positive biopsy specimen was from a case seen in 1932 (fig 4), the oldest specimen examined. All sections were negative for the presence of HPV6 DNA.

HPV 16 positivity was focally distributed within the tumour and most of the tumour cells were negative. HPV DNA was shown more often and most strongly in maturing cells in differentiated areas of tumour. Although a strong signal for HPV DNA was detected from individual tumour cells, no HPV structural antigens were detected in any of the tumours tested.

\section{Discussion}

In CIN, HPV sequences were detected in $49 \%$ of biopsy specimens: $6(60 \%)$ of CIN1 but only $7(41 \%)$ of CIN3 were positive. The sensitivity of the technique for the detection of HPV in CIN was greater than that for the immunocytochemical demonstration of viral structural antigens, ${ }^{13}$ but was less than that of Southern blot analysis. ${ }^{3}$ Like structural antigens, HPV DNA was detected in greatest quantity in the superficial

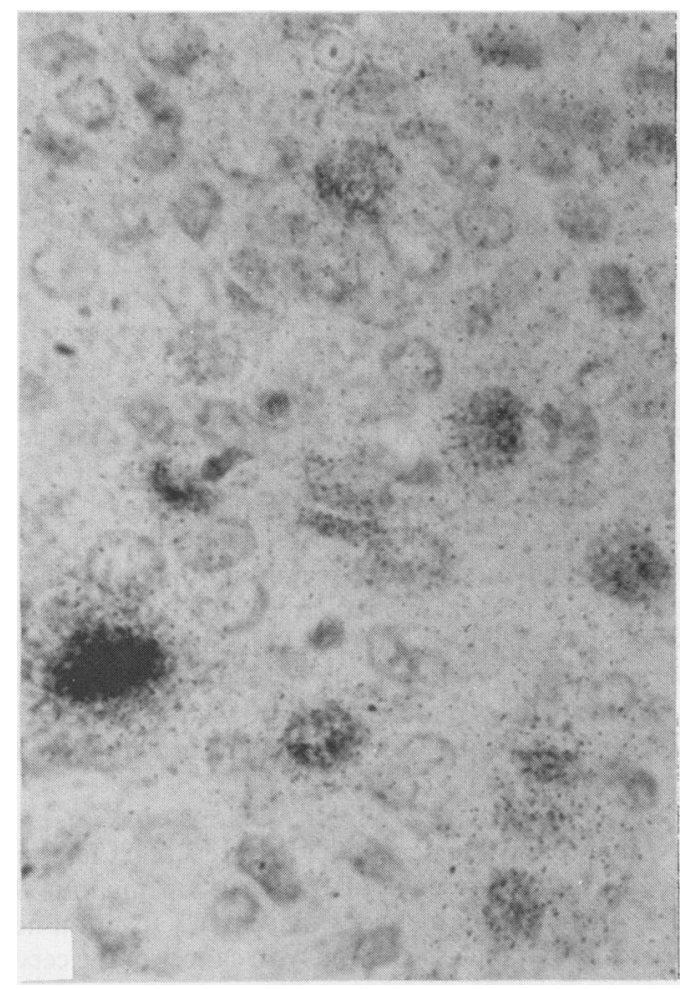

Fig 4 Autoradiograph of section of invasive cervical cancer biopsy specimen taken in 1932.

parts of the epithelium in differentiated cells. The signal was often greatest in cells showing koilocytic change, and in double stained preparations, was detected in association with structural antigens. HPV DNA, however, was also detected in sections without koilocytes and in cells in the less differentiated areas of the parabasal region which did not contain viral structural antigens. The distribution was similar to that reported previously for HPV6 in condylomata acuminata and in a single case of CIN for HPV16. ${ }^{21}$

The detection rate of HPV16 DNA in invasive cervical carcinoma was greater than that for the detection of HPV in CIN. Of the sections which processed satisfactorily, $20(80 \%)$ were positive for HPV16 DNA sequences. This is comparable with the results obtained for the Southern blot technique on freshly frozen tissues. ${ }^{3}$ The distribution of HPV positive cells was focal and these were usually in areas of differentiation, but HPV16 DNA could also be detected in some apparently less well differentiated cells in the invasive tumours.

The explanation for the focal distribution of positive cells in invasive tumours probably lies in the copy number of HPV DNA in tumour cells relative to the sensitivity of HPV DNA detection by in situ 
hybridisation. Southern blotting showed a low average copy number for HPV DNA in tumour cells, in the range of 1-50 copies per cell. This low copy number probably results from integration of HPV DNA into the DNA of malignant cells and is at the borderline of the sensitivity of detection by in situ hybridisation. Comparison of the signal over the focal, strongly positive cells with that of cell lines indicates that the copy number is comparable with that in Caski cells, ${ }^{18}$ and is in the range of $100-600$ copies per cell. It is not clear why some cells should contain a high copy number of HPV DNA sequences. Some tumours have been shown to contain HPV DNA integrated in head to tail tandem repeats as well as free unintegrated forms. ${ }^{1-3}$ The free forms of HPV DNA may be those detected in the focally distributed positive cells, or that, through homologous recombination, the head to tail tandem repeats produce free, unintegrated copies which can replicate to a high copy number. Differentiation of the tumour cells may initiate this DNA replication in a manner analogous to that seen in differentiating squamous epithelium in condylomata and CIN.

The finding of HPV16 DNA in biopsy specimens of invasive cervical cancer taken over 50 years ago and the consistent presence of the virus throughout the subsequent period indicates that HPV16 is not a new virus and that the association with cancer of the cervix is a long established one. The recent increase in detected HPV infection of the lower genital tract and in associated intraepithelial neoplasia and invasive cancer cannot, therefore, be ascribed to a new type of HPV infection. A more likely explanation would be that changes in sexual habits have resulted in an increase of transmission of the virus. We have previously shown that HPV infection was found with the same prevalence in CIN lesions in a high risk group of women examined in Holloway prison in London during the early 1970 s as in our current clinic population. ${ }^{22}$ Changes in behaviour may have led to a spread of this infection into the general population. ${ }^{23}$

Although the sensitivity of in situ hybridisation is at present superior to immunohistochemisty as it is both specific and more sensitive, it is not as sensitive as Southern blotting. The requirement for radiolabelling of probes also limits its present application as a diagnostic method, but it is useful in the localisation of HPV DNA replication in CIN and invasive cancer and in the demonstration of the long history of the association between HPV16 and cervical carcinoma.

We thank Dr S Rasbridge for assistance with retrieval of archived material, and $\mathrm{Mr} \mathbf{R}$ Yabsley, $\mathrm{Mr} \mathbf{P}$ Maddox, and staff of the histopathology department of the Whittington Hospital for expert technical assistance and considerable help. We are grateful to
Mr A Singer for permission to study his cases, and to the North East Thames Regional Health Authority and the Cancer Research Campaign for generous financial support.

\section{References}

I Durst M, Gissmann L, Ikenberg H, zur Hausen H. Papillomavirus DNA from a cervical carcinoma and its prevalence in cancer biopsy samples from different geographical regions. Proc Natl Acad Sci USA 1983;80:3812-5.

2 Boshart M, Gissman L, Ikenberg H, Kleinheinz A, Scheurlen W, zur Hausen $H$. A new type of papillomavirus DNA, its presence in genital cancer biopsies and in cell lines derived from cervical cancer. EMBO J 1984;3:1151-7.

3 McCance DJ, Campion MJ, Clarkson PK, Chesters PM, Jenkins $D$, Singer A. The prevalence of human papillomavirus type 16 DNA sequences in cervical intraepithelial neoplasia and invasive carcinoma. Br J Obstet Gynaecol 1985;92:1101-5.

4 Gissman L, Wolnik L, Ikenberg H, Koldovsky U, Schnurch HG, zur Hausen H. Human papillomavirus type 6 and 11 DNA sequences in genital and laryngeal papillomas and in some cervical cancers. Proc Natl Acad Sci USA 1983;80:560-3.

5 McCance DJ, Lowe D, Simmons P, Thomson JPS. Human papillomavirus in condylomata acuminata of the anus. $J$ Clin Pathol 1984;39:927.

6 McCance DJ. Human papillomavirus and cancer. Biochim Biophys Acta 1986;ii:237-40.

7 Campion MJ, McCance DJ, Cuzick J, Singer A. The progressive potential of mild cervical atypia: a prospective cytological, colposcopic and virological study. Lancet 1986;ii:237-40.

8 Lorincz AT, Lancaster WD, Temple GF. Cloning and characterisation of the DNA of a new human papillomavirus from a woman with dysplasia of the uterine cervix. $J$ Virol 1986;58: 225-8.

9 Beral V, Booth M. Predictions of cervical cancer incidence and mortality in England and Wales. Lancet 1986;i:495.

10 Jenkins D, Tay SK, McCance DJ, Campion MJ, Clarkson PK, Singer A. Histological and immunocytochemical study of cervical intraepithelial neoplasia (CIN) associated with HPV6 and HPV16 infections. J Clin Pathol 1986;39:1177-80.

11 Schneider A, Kraus H, Schuhmann R, Gissman L. Papillomavirus infection of the lower genital tract: detection of viral DNA in gynaecological swabs. Int J Cancer 1985;35:443-8.

12 McCance DJ, Campion MJ, Singer A. Non-invasive detection of cervical papillomavirus DNA. Lancet 1986;i:558-9.

13 Jenkins D, Maddox P, Tay SK. An evaluation of routine HPV common antigen staining of colposcopic cervical biopsies. J Clin Pathol 1987;40:1212-16.

14 McDougall JK, Myerson D, Beckmann AM. Detection of viral DNA and RNA by in situ hybridisation. $J$ Histochem Cytochem 1986;34:33-7.

15 Moench TR, Gendelman HE, Clements JE, Opendra N, Griffin DE. Efficiency of in situ hybridisation as a function of probe size and fixation techniques. $J$ Virol Methods 1985;11:119-30.

16 Tourtellotte WW, Verity AN, Schmid P, Martinez S, Shapshale P. Convalent binding of formalin fixed paraffin embedded brain tissues sections to glass slides suitable for in situ hybridisation. J Virol Methods 1987;15:87-99.

17 Maddox P, Jenkins D. 3-amino-propylethoxysilane (APES): a new advance in section adhesion. J Clin Pathol 1987;40:1256-7.

18 Rigby PWS, Dieckman M, Rhodes C, Berg P. Labelling deoxyribonucleic acids to high specific activity in vitro by nick translation with DNA polymerase. J Mol Biol 1977;113:247-51.

19 Gendelman HE, Moench TR, Narayan O, Griffin DE, Clements JE. A double labelling technique for performing immunocytochemistry and in situ hybridisation in virus infected cell cultures 
and tissues. J Virol Methods 1985;93:93-103.

20 Yee C, Krishnan-Hewlett I, Baker CC, Schlegel R, Howley PM. Presence and expression of human papillomavirus sequences in human cervical carcinoma cell lines. Am J Pathol 1985;119: $361-4$.

21 Stoler MH, Broker TR. In situ hybridisation detection of human papillomavirus DNAs and messenger RNAs in genital condylomas and a cervical carcinoma. Hum Pathol 1986;17:1250-8.

22 Singer A, Wilters J, Walker P, et al. A comparison of the prevalence of human papillomavirus antigen in biopsies from women with cervical intraepithelial neoplasia in the early 1970s and 1980s. J Clin Pathol 1985;38:855-7.

23 Jenkins D, Tay SK, Dyson JL. Koilocytic frequency and the prevalence of cervical human papillomavirus infection. Lancet 1986;i:557-8.

Requests for reprints to: Dr D J McCance, Department of Microbiology, UMDS, Guy's Campus, London Bridge, London SE1 9RT, England. 